\title{
PENILAIAN KINERJA TU (TATA USAHA) UNIVERSITAS ISLAM LAMONGAN
}

\author{
Nur Nafi'iyah \\ Dosen Program Studi Teknik Informatika, Fakultas Teknik, Universitas Islam Lamongan \\ Jl. Veteran No. 53 A Lamongan \\ Telp. (0322) 324706 \\ E-mail: nafik_unisla26@yahoo.co.id
}

\begin{abstract}
The performance assessment of administration staff in the college did in order to improve the quality of the service process and internal continuous quality improvement. This study aims at the development of information systems web-based performance assessment. This system was built using the programming language PHP (Hypertext Processor) and MySql database, which is expected to provide a more efficient and effective in conducting this evaluation, all the colleges are trying to have an information system that not only presents a variety of important information, but also can perform the data processing. Assessmentof the performance is measurements made on various activities with the questioner. The results of the study give a rank of accumulation is obtained by calculating the second component of the assessment, the results of this can be seen anyone to find the highest rank to lowest. It is hoping that every values obtained can push Employees the administration in Lamongan Islamic university to improve its performance.
\end{abstract}

Keywords: performance appraisal, administration Lamongan Islamic University

\section{PENDAHULUAN}

TU (Tata Usaha) adalah kegiatan untuk mengadakan pencatatan dan penyusunan data administrasi tentang sebuah instansi sehingga data tersebut digunakan secara langsung sebagai bahan informasi bagi pimpinan instansi yang bersangkutan atau dapat dipergunakan oleh siapa saja yang membutuhkannya. Peran tata usaha di sebuah instansi sangatlan penting karena untuk menunjang kelancaran kegiatan di dalam sebuah instansi. TU (Tata Usaha) juga melayani pelaksanaan sesuatu pekerjaan operatif dengan menyediakan data yang diperlukan kantor.

TU (Tata Usaha) bersifat membantu atau menunjang kelancaran pekerjaan pokok sebuah instansi, sehingga TU (Tata Usaha) merupakan keseluruhan proses kerjasama antara dua orang/lebih yang didasarkan atas rasionalitas tertentu untuk mencapai tujuan yang telah disepakati bersama. Pekerjaan TU (Tata Usaha) selalu berhubungan dengan pekerjaan-pekerjaan lainnya dalam sebuah instansi. TU (Tata Usaha) membantu memperlancar semua pekerjaan pada sebuah instansi, dengan menyediakan arsiparsip penting yang dibutuhkan oleh suatu bagian dalam menunjang pelaksanaan pekerjaan pada bagian tersebut, agar TU (Tata Usaha) dapat berjalan dengan baik dan maksimal, maka diperlukan suatu sistem tata usaha yang baik, di mana urutan pekerjaan tata usaha harus disusun dan dijalankan dengan teratur. Persepsi mahasiswa terhadap kualitas layanan kinerja TU (Tata Usaha) di Perguruan tinggi merupakan penilaian menyeluruh atas keunggulan suatu layanan administrasi dalam sebuah universitas. Saat ini, semua perguruan tinggi berusaha untuk memiliki sebuah sistem informasi yang tidak hanya menyajikan berbagai informasi - informasi penting, melainkan juga dapat melakukan pengolahan data didalamnya. Tolak ukur kinerja TU (Tata Usaha) sebuah universitas dapat dilihat dari pelayanan yang diberikan kepada mahasiswanya.

Melihat pentingnya pengukuran tingkat kepuasan mahasiswa terhadap evaluasi kinerja TU, dibutuhkan suatu wadah pengukuran tingkat kepuasan mahasiswa. Merujuk dari permasalan di atas sudah selayaknya dikembangan sistem informasi penilaian kinerja karyawan TU ( Tata Usaha) berbasis web yang memungkinkan kemudahan akses bagi karyawan dalam hal ini adalah TU ( Tata Usaha) universitas dalam melakukan evaluasi kinerja. Selain itu sistem informasi tersebut dapat digunakan sebagai alat untuk mengolah data, melakukan monitoring dan evaluasi kinerja karyawan TU (Tata Usaha). Diharapkan lebih efektif dan tidak memakan biaya.

Tujuan penelitian ini adalah: Untuk mengembangkan perangkat pengukur tingkat 
kepuasan mahasiswa terhadap pelayanan kinerja TU di Universitas Islam Lamongan yang dikemas dalam bentuk aplikasi berbasis web. Untuk menghasilkan perangkat pengukur tingkat kepuasan mahasiswa terhadap pelayanan kinerja $\mathrm{TU}$ di Universitas Islam Lamongan yang dikemas dalam bentuk aplikasi berbasis web.

Berdasarkan teori yang berhubungan dengan sistem Informasi yang penulis buat, untuk dijadikan sebagai bahan masukan guna ketepatan pelaksaan sistem diuraikan sebagai berikut :

Pengukuran kinerja merupakan salah satu instrumen yang dipandang efektif sebagai pijakan untuk meningkatkan kinerja secara keseluruhan, yang dapat membantu organisasi untuk membandingkan rencana masa lalu dengan strategi masa depan, serta mengatur target kinerja. Penilaian kinerja juga memiliki fungsi menanggapi kebijakan dan pemersatu target individu dan organisasi.

Melakukan penelitian tentang Perangkat pengukur tingkat kepuasan mahasiswa terhadap proses pembelajaran di jurusan teknik mesin universitas negeri semarang untuk mengembangkan perangkat pengkur tingkat kepuasan mahasiswa terhadap proses pembelajaran yang dikemas dalam bentuk aplikasi berbasis web. Penelitian ini menggunakan metode penelitian dan pengembangan pendidikan (Educational Research and Development) dengan model 4D (define, design, develop, dan disseminate). Berdasarkan hasil penelitian diharapkan perangkat pengukur tingkat kepuasan mahasiswa terhadap proses pembelajaran yang berbasis web dapat mempermudah Jurusan Teknik Mesin Universitas Negeri Semarang dalam melakukan evalusai system pembelajaran [4].
Berdasarkan penelitian M. Miftakul Amin (2012) yang berjudul Pengembangan Sistem Informasi Penilaian Indeks Kinerja Dosen dan Karyawan Perguruan Tinggi Darmajaya Berbasis Intranet. Perguruan Tinggi Darmajaya menerapkan sebuah instrument pengukuran penilaian bagi seluruh dosen dan karyawan dengan menggunakan parameter-parameter tertentu. Instrumen ini bertujuan untuk meningkatkan kinerja segenap dosen dan karyawan yang ada di Perguruan Tinggi Daramajaya. Di sisi lain, untuk mengolah data dan menghasilkan informasi IKD dan IKK saat ini belum terdapat perangkat lunak komputer yang tepat, sejalan dengan fasilitas infrastruktur teknologi informasi yang tersedia [1].

Berdasarkan penelitian A. Aviv Mahmudi (2015) yang berjudul Sistem Informasi Penilaian Kinerja Dosen Dan Karyawan Berbasis Web. Penilaian kinerja dosen dan karyawan dari perguruan tinggi dilakukan dalam rangka meningkatkan kualitas proses pembelajaran serta peningkatan kualitas internal yang berkelanjutan. STIE 'YPPI' Rembang melakukan penilaian kinerja dosen dan karyawan setiap akhir semester gasal dan genap. Penilaian kinerja selama ini dilakukan secara manual dengan melakukan penyebaran kuesioner, melalui persepsi mahasiswa, rekan sejawat serta atasan langsung [3].

\section{METODE PENELITIAN}

Sistem informasi yang dibangun menggunakan web menggunakan jaringan internet, Sehingga dapat dimanfaatkan dengan menggunakan browser. Script pemrograman yang digunakan adalah PHP dan database server MySQL. Berikut ini merupakan gambaran umum sistem yang akan dibuat, dalam Gambar 1:

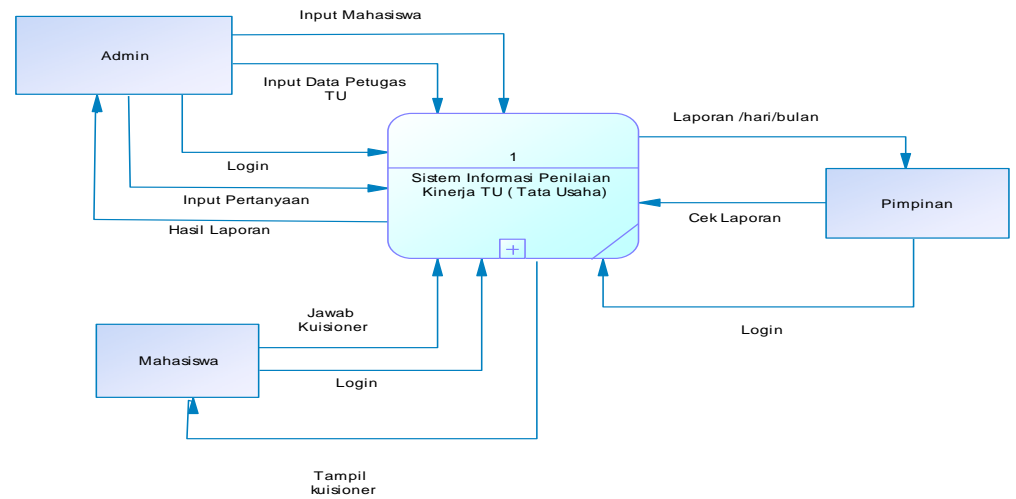

Gambar 1. Diagram Konteks 
Sistem ini memiliki 2 entity yaitu Administrator dan User (mahasiswa dan pemimpin). Kedua Entity tersebut berpengaruh pada keberhasilan sistem ini. Penjelasan pengaruh entity pada sistem adalah sebagai berikut: Admin adalah pihak yang bertugas melakukan input pengetahuan pada sistem. Kemampuan seorang administrator sekaligus sebagai peneliti merupakan faktor utama yang mempengaruhi berhasil atau tidaknya pembuatan sistem tersebut yang mempengaruhi keakuratan sistem dalam memecahkan masalah. Adapun tugas admin adalah memasukkan berbagai data antara lain:

1) Input data Karyawan

2) Input data Kuisioner

Untuk dapat melakukan pengelolaan data berupa input, update dan delete maka admin harus melakukan login.

Pengguna atau user juga mempengaruhi hasil dari penilaian. Kemampuan pemahaman seorang user dalam berinteraksi dengan sistem akan berpengaruh besar terhadap diagnosa yang akan dihasilkan oleh sistem. Adapun tugas dan hak dari user antara lain:

1) Mengisi kuisioner

2) Pengguna dapat melihat data konten

3) Jika ingin melakukan penilaian, maka penggua tidak perlu login pada sistem.

4) Pengguna melakukan penilaian dengan menjawab pertanyaan yang akan ditampilkan system

5) Setelah memasukkan mengisi pertanyaan yang diberikan oleh sistem, maka sistem akan menyimpan dan merekap dalam bentuk laporan yang akan disampaikan kepada pemimpin

Database dalam pembuatan Sistem Informasi Penilaian Kinerja TU (Tata Usaha) Universitas Islam Lamongan Berbasis Web ini menggunakan MySQL yang mana ada 5 tabel yang terdiri dari: Tabel fakultas, tabel karyawan, tabel kuis, tabel soal, tabel user.

Tabel user berfungsi untuk menyimpan semua data atau informasi user/pengguna yang akan digunakan untuk mendukung sistem ini. Tabel user memiliki lima atribut yaitu Id_user, nama, username, password, level:
Tabel 1. User

\begin{tabular}{cllll} 
No & $\begin{array}{l}\text { Nama } \\
\text { Field }\end{array}$ & Type & Size & Ket \\
\hline 1. & id_user & Int & 10 & $\begin{array}{l}\text { Primary } \\
\text { Key }\end{array}$ \\
2. & Nama & Varchar & 50 & \\
3. & Username & Varchar & 50 & \\
4. & Password & Varchar & 100 & \\
5. & Level & Varchar & 20 & \\
\hline
\end{tabular}

Tabel karyawan berfungsi untuk menyimpan semua data atau informasi karyawan yang akan digunakan untuk mendukung sistem ini. Tabel karyawan memiliki empat atribut yaitu Id_karyawan, Nik, nama, image, id_fakultas:

Tabel 2. Karyawan

\begin{tabular}{lllll}
\hline No & $\begin{array}{l}\text { Nama } \\
\text { Field }\end{array}$ & Type & Size & Ket \\
\hline 1. & $\begin{array}{l}\text { id_karyawa } \\
\text { n }\end{array}$ & Int & 5 & $\begin{array}{l}\text { Primary } \\
\text { Key }\end{array}$ \\
2. & Nik & $\begin{array}{l}\text { Varcha } \\
\text { r }\end{array}$ & 50 & \\
3. & Nama & $\begin{array}{l}\text { Varcha } \\
\text { r }\end{array}$ & 100 & \\
4. & Image & $\begin{array}{l}\text { Varcha } \\
\text { Imak }\end{array}$ & 50 & \\
5. & id_fakultas & Int & 5 & \\
\hline
\end{tabular}

Tabel kuis berfungsi untuk menyimpan semua data atau informasi kuis yang akan digunakan untuk mendukung sistem ini. Tabel kuis memiliki tujuh atribut yaitu Id_jawab, Nim, nama, id_soal, id_fakultas, id_karyawan, nilai:

Tabel 3. Kuis

\begin{tabular}{cllll}
\hline No & $\begin{array}{l}\text { Nama } \\
\text { Field }\end{array}$ & Type & $\begin{array}{l}\text { Siz } \\
\text { e }\end{array}$ & Ket \\
\hline 1. & Id_jawab & Int & 20 & $\begin{array}{l}\text { Primary } \\
\text { Key }\end{array}$ \\
2. & Nim & Varchar & 50 & \\
3. & Nama & Varchar & 100 & \\
4. & Id_soal & Int & 5 & \\
5. & Id_fakulta & Int & 5 & \\
& s & & & \\
6. & Id_karya & Int & 5 & \\
& wan & & & \\
7. & Nilai & Int & 50 & \\
\hline
\end{tabular}

Tabel Fakultas berfungsi untuk menyimpan semua data atau informasi fakultas yang akan digunakan untuk mendukung sistem ini. Tabel fakultas memiliki dua atribut yaitu Id_fakultas, fakultas: 
Tabel 4. Fakultas

\begin{tabular}{cllcl}
\hline No & $\begin{array}{l}\text { Nama } \\
\text { Field }\end{array}$ & Type & Size & Ket \\
\hline 1. & Id_fakultas & Int & 5 & $\begin{array}{l}\text { Primar } \\
\text { y Key }\end{array}$ \\
2. & Fakultas & Varchar & 50 & \\
\hline
\end{tabular}

Tabel soal berfungsi untuk menyimpan semua data atau informasi soal yang akan digunakan untuk mendukung sistem ini. Tabel soal memiliki dua atribut yaitu Id_soal, soal:

Tabel 5. Soal

\begin{tabular}{lllcl}
\hline No & $\begin{array}{l}\text { Nama } \\
\text { Field }\end{array}$ & Type & Size & Ket \\
\hline 1. & Id_soal & Int & 5 & $\begin{array}{l}\text { Primar } \\
\text { y Key }\end{array}$ \\
2. & Soal & Varchar & 50 & \\
\hline
\end{tabular}

Kuesioner kinerja karyawan TU (Tata Usaha) oleh mahasiswa, sebagai berikut:

a. Petugas TU dalam memberikan informasi kepada mahasiswa dengan baik dan jelas.

b. Petugas TU memberikan pelayanan dengan baik.

c. Petugas TU bersikap ramah dalam melayani mahasiswa

d. Petugas TU memberikan pelayanan kepada mahasiswa dengan cepat

e. Petugas TU terbuka terhadap kritik dan saran dari mahasiswa

f. Kesungguhan dalam melaksanakan pekerjaan (Rencana Mutu, Prosedur Kerja, Prosedur Mutu)

g. Kemampuan mengendalikan diri dalam berbagai situasi dan kondisi

h. Memiliki kemampuan memberikan pelayanan prima terhadap mahasiswa

i. Kemampuan menggunakan media teknologi informasi

j. Menguasai bidang keahlian yang menjadi tugas pokoknya

Responden: Masing-masing mahasiswa di tiap fakultas di UNISLA, Berikut Nama Fakultas di Universitas Islam Lamongan:

1. Fakultas agama islam

2. Fakultas Keguruan dan Ilmu Pendidikan

3. Fakultas Ekonomi

4. Fakultas Hukum

5. Fakultas Teknik

6. Fakultas peternakan
7. Fakultas Perikanan

8. Fakultas Kesehatan

Sistem akan melakukan perhitngan berdasarkan parameter yang telah ditentukan, berikut parameter penilaian:

Tabel 6. Parameter Penilaian

\begin{tabular}{cl}
\hline Point & Keterangan \\
\hline 1 & Tidak suka \\
2 & Kurang suka \\
3 & Suka \\
4 & Sangat suka \\
\hline
\end{tabular}

Terdapat dua macam laporan yang nantinya akan dihasilkan oleh sistem untuk pengguna dengan tipe manajer ataupun direktur, antara lain:

1. Laporan harian yang berkaitan dengan performa staff administrasyang direkap per hari di dalam berisi tanggal kuisioner.

2. Laporan yang berkaitan dengan jumlah pengujian yang masuk ke dalam sistem, berapa jumlah pengujian yang masuk, jumlah pengujian yang diterima, jumlah pengujian yang ditolak, jumlah pengujian yang selesai dikerjakan tepat waktu, dan jumlah pengujian yang selesai dikerjakan terlambat tiap bulannya.

\section{HASIL DAN PEMBAHASAN}

Berdasarkan hasil rancangan yang telah dilakukan menghasilkan implementasi Sistem Informasi Penilaian Kinerja TU (Tata Usaha) Universitas Islam Lamongan Berbasis Web. Hasil dari penelitian ini berupa aplikasi yang dijalankan melalui jaringan localhost.

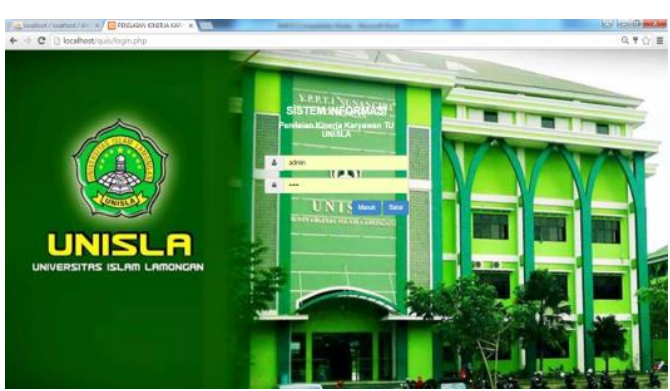

Gambar 2. Login

Login digunakan untuk memberikan otentikasi user. User akan memasukkan dua input (username dan password) melalui 
keyboard. Kemudian sistem memeriksa kedua username dan password untuk melihat apakah keduanya valid, seperti dalam Gambar 2.
User dalam hal ini adalah mahasiswa dapat mengisi kuesioner penilaian karyawan TU unisla, adapun tampilan sistem untuk melakukan kuisioner dalam Gambar 3.

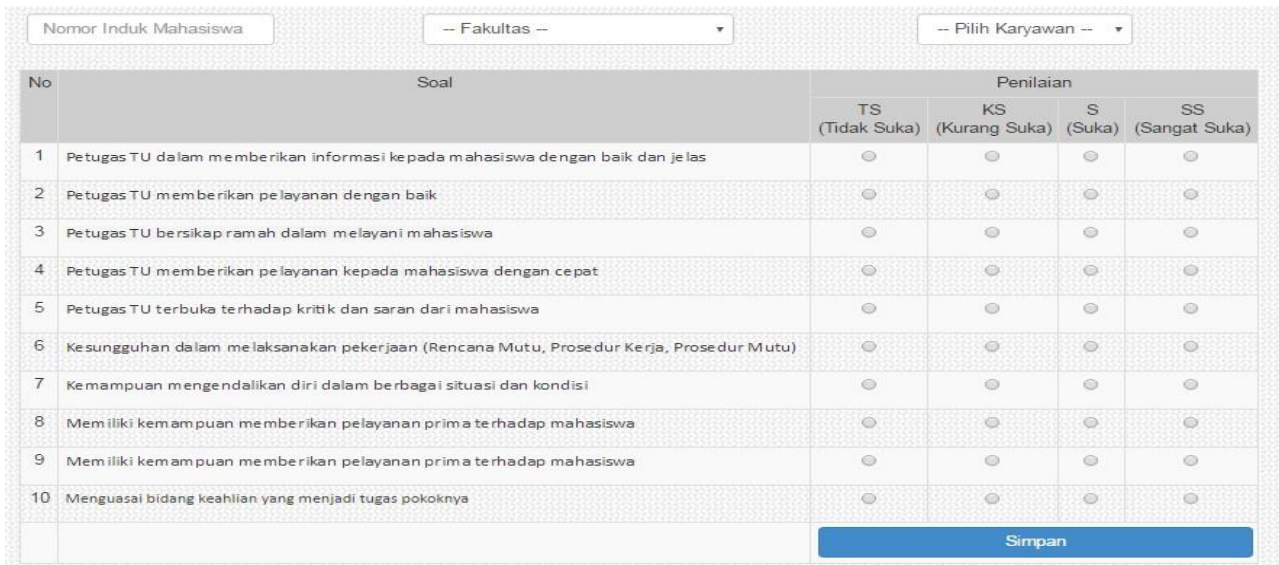

Gambar 3. Kuisioner

Pada Halaman ini admin dapat memperoleh informasi berupa laporan hasil kuisioner.
Laporan terdiri dari laporan harian dan laporan bulanan, seperti Gambar 4.

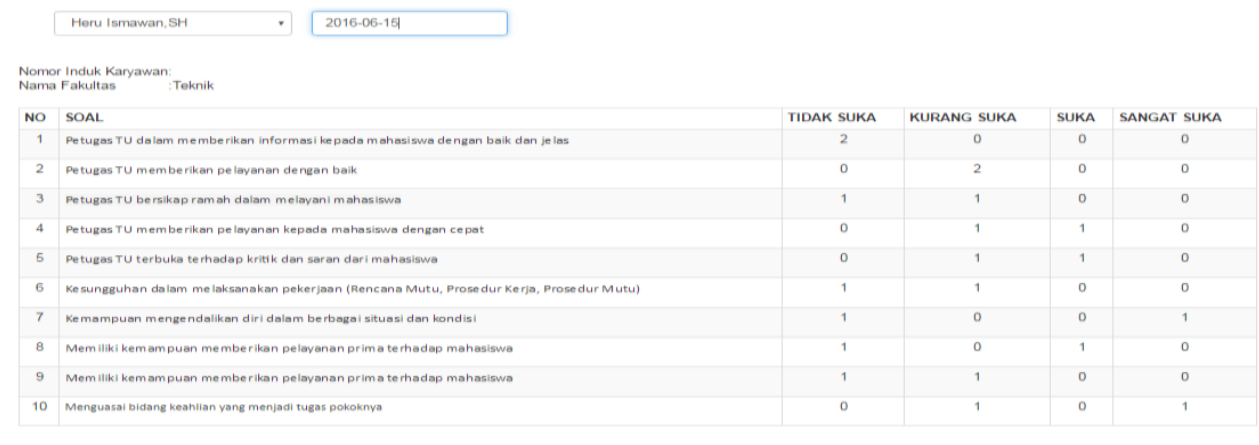

Gambar 4. Halaman Laporan Harian

Setelah mahasiswa pengisian kuesioner, maka akan ditampilkan laporan hasil penilaian yang nantinya akan dilaporkan kepada pimpinan, dalam Gambar 5.

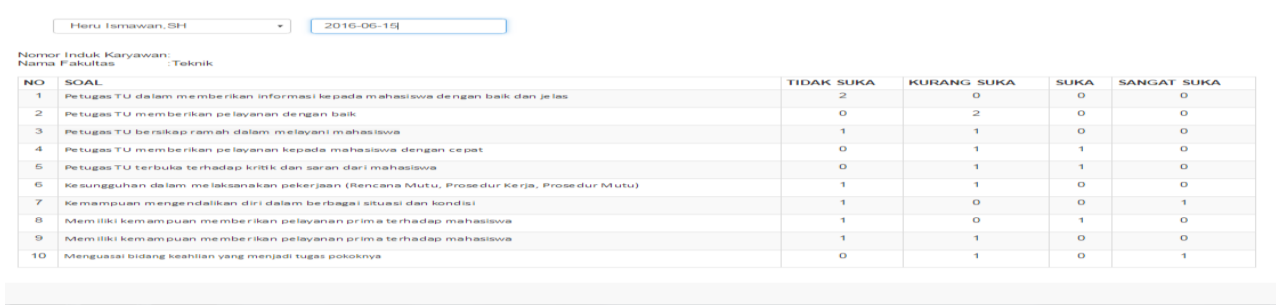

\section{Gambar 5. Laporan Bulanan}

\section{KESIMPULAN}

Sistem ini sangat bermanfaat jika diterapkan untuk masyarakat umum karena pengoperasiannya sangat mudah dan bisa diakses di mana-mana dan kapan saja dengan koneksi internet, sehingga memudahkan dalam memperoleh informasi penilaian kinerja Dari hasil penelitian tersebut maka dapat disimpulkan bahwa: Aplikasi ini dibangun sistem informasi menggunakan PHP MySQL berbasis web. Dengan adanya aplikasi ini dapat melakukan penilaian tanpa perlu menyebar 
angket secara manual kepada setiap mahasiswa, sistem ini berbasis Web jadi pengguna bisa mengoprasikan aplikasi ini dengan menggunaka hp atau computer. Hasil berupa Laporan dalam bentuk table. Laporan hasil evaluasi dapat dijadikan pijakan manajemen universitas untuk memberikan reward bagi karyawan.

\section{REFERENSI}

[1] Amin M. Miftakul. 2012. Pengembangan Sistem Informasi Penilaian Indeks Kinerja Dosen dan Karyawan Perguruan Tinggi Darmajaya Berbasis Intranet. http://news.palcomtech.com/wpcontent/upl oads/2012/08/MIFTAHUL_TE020220121. pdf . (05 Maret 2016)
[2] Jalaliyoon, N., dan Taherdoost, H., 2012. Performance Evaluation Of Higher Education; a Necessity. Procedia-Social and Behavioral Sciences, 46, 5682-5686.

[3] Mahmudi A. Aviv. 2015. Sistem Informasi Penilaian Kinerja Dosen dan Karyawan Berbasisweb.

http://36.78.223.213/ejurnal/index.php/3/a rticle/viewFile/12/13. (di akses 11 Maret 2016).

[4] Setiawan Arta Efy. 2013. Perangkat Pengukur Tingkat Kepuasan Mahasiswa Terhadap Proses Pembelajaran Di Jurusan Teknik Mesin Universitas Negeri Semarang.

http://lib.unnes.ac.id/17984/1/5201408110. pdf. (05 Maret 2016) 